\title{
Direito Penal Ecológico
}

\author{
Paulo José da Costa Junior \\ Catedrático de Direito Penal da Faculdade \\ de Direito da Universidade de São Paulo.
}

SUMĀRIO: 1. Breve esforço histórico - 2. O Direito Ecológico como ramo do Direito Social - 3. Aplicasão extensiva de Norma Penal - 4. Convem incriminar a conduta antiecologica? - 5. Onde inserir o crime ecolbgico? - 6. O tipo penal. - 7. Dano e perigo. - 8. Eximentes. - 9. O elemento subjetivo. - 10. Sansōes. 11. - o C6́digo Penal Brasileiro.

1. Antes do progresso científico e tecnológico, do desenvolvimento demográfico industrial, antes que os hidrocarburantes, anticriptógamos e fertilizantes alterassem a imagem da natureza não se pensou em tutelar a ecologia.

Assim é que todas as legislações a respeito sucederam a revolução industrial. A "water pollution central act", nos Estados Unidos, é de 1948. "A réparation des eaux et a la lutte contre leur pollution", em França, é de 1964. Na Alemanha, Rússia e Noruega a legislação ecológica data de 1960. Na Suécia, de 1969 e na Hungria, de 1976.

Somente a velha Inglaterra preocupou-se, há mais de um século, com o problema. Em 1876, elaborou o seu "rivers pollution prevention act", atualizado posteriormente pela lei de 1951.

Medidas de caráter internacional, ou regional, foram tomadas, principalmente no campo hídrico. A declaração firmada pela ONU, em Estocolmo, em junho de 1976, sobre o meio ambiental humano é decisiva. E o Conselho da Europa, pouco depois, reconheceu o direito do homem de desfrutar de um ambiente são, de respirar um ar puro, de beber água não poluída, de ser protegido contra rumores excessivos e substâncias nocivas, de ter livre acesso ao mar e à montanha.

No campo do direito, a tutela principiou por ser civil. Era o proprietário do fundo do vale que fazia valer os seus direitos, contra o proprietário morro acima que emporcalhava a água, de uso comum. A "actio finium regundorum" dizia respeito ao interesse privatístico, regulando relações de vizinhança, sem que houvesse qualquer dano à coletividade.

Posteriormente, algumas normas, já de caráter social, foram elaboradas, no setor da segurança e higiene no trabalho, ou para regula- 
mentar a atividade de indústrias insalubres e perigosas. Mesmo assim, a poluição ambiental ainda não estava em jogo. As normas jurídicas, entretanto, abandonaram o aspecto da mera relação de vizinhança para se revestirem da moldura publicística adequada. Fez-se mister autorização para o funcionamento de determinadas indústrias, bem como foi estabelecido um controle sobre o seu funcionamento.

Finalmente, aos poucos, foi-se estabelecendo uma legislação ecológica, para assegurar o uso equilibrado dos recursos naturais. Para tanto, normas administrativas, por vezes reforçadas pela sanção penal, foram estabelecidas em todo o mundo.

2. O Estado não se preocupava, a princípio, com as necessidades do homem, mas apenas com seus direitos e liberdades fundamentais. Influenciado pelo mito do progresso econômico, o Estado procurava assegurar princípios liberais da tutela integral da propriedade e da ampla liberdade de qualquer iniciativa em qualquer campo. Ora, o direito ecológico era contraditório a tais princípios.

Para que pudesse surgir o direito ecológico, foi necessário que se passasse, dos direitos da pessoa, à defesa da pessoa social. As liberdades individuais foram perdendo seu traço egoístico, para assumirem uma dimensão social. Reconheceram-se limitações aos direitos de propriedade e à livre iniciativa econômica. Surgiu, dessarte, a imagem social do homem. Com ela, o direito penal social, do qual faz parte o direito penal ecológico, já que o homem retira da natureza os meios necessários à sua existência. A ecologia, portanto, constitui um bem social. E a garantia de se usufruir de um meio ambiental puro configura um direito social de todo cidadão.

3. A jurisprudência italiana procedeu a perigosa aplicação extensiva da norma penal, em matéria ecológica. Procurou desse modo suprir a lacuna legislativa.

Exemplifiquemos com o preceito contido no artigo 439 do código penal italiano, que pune "envenenamento de água ou substâncias destinadas à alimentação". Sustentou-se então que a locução "destinadas à alimentação" se referia apenas à substância. Conseqüentemente, passou-se a punir todo aquele que procedesse a qualquer envenenamento de água, ainda que não destinada à alimentação.

Embora o intérprete deva emprestar à norma a acepção, mais conforme aos reclamos da atualidade, é deveras condenável semelhante analogia, que põe em risco a certeza do direito.

4. Estamos em um momento de esvaziamento da parte especial do código penal, em que a descriminalização constitui a tônica dominante. Além do mais, na maioria dos países de civilização mais avançada, prepondera atualmente o princípio de intervenção mínima do Estado, em matéria penal. Procura-se dessa forma eliminar a tendência, em tempos de antanho predominante, de resolver $o$ relacionamento autoridade-cidadão em favor da primeira. 
Por outro lado, o direito penal apresenta-se falido, no que diz respeito à pena de prisão. A moderna tendência é reservar o cárcere para os crimes de maior violência, relegando o maior número de crimes a meros ilícitos administrativos ou civis.

Diante de tais considerações, cumpre indagar: convém incriminar a conduta antiecológica? Entendemos que sim. Os abusos são tais e tamanhos, que se faz mister a "última ratio" da sansão penal. De mais a mais, o direito penal tem criado novas figuras penais, ao tutelar a intimidade, a segurança do trabalho, ao reprimir as fraudes alimentares, ou ao ocupar-se da criminalidade econômica.

Parece fora de dúvida a necessidade imperiosa e imediata da incriminação. Não só pelo empobrecimento dos recursos naturais, como principalmente pela necessidade de melhorar a qualidade de vida e assegurar o direito do cidadão de trabalhar e viver num ambiente puro.

5. Estabelecida a necessidade da incriminação, resta indagar: onde inserir um novo tipo ecológico? Na parte especial do código penal? Ou num direito penal administrativo, secundário ou especial?

A degradação ambiental não pode ser combatida apenas com normas penais. Vale dizer, não basta o instrumental repressivo, fazendo-se igualmente necessária a disciplina administrativa, voltada essencialmente à prevenção.

Assim, a intervenção penal em matéria ecológica assumiria papel acessório, com respeito ao direito administrativo. Na parte penal, restariam tão-somente aquelas violações intoleráveis à esfera pessoal do indivíduo.

Um outro aspecto nos leva ainda a concluir pela inclusão do direito penal ecológico numa legislação especial, fora portanto do código penal. É que, no código penal, está consagrado o princípio da responsabilidade penal de natureza eminentemente pessoal ("societas delinquere non potest", "singulorum proprium est maleficium", "peccata suos teneant auctores"). Não só está consagrado o princípio historicamente, como ainda por um aspecto lógico, não se pode responsabilizar penalmente a pessoa jurídica. Com efeito, como endereçar o juízo de reprovação à empresa, que não se apercebe do caráter aflitivo ou reeducativo da pena.

Faz-se mister, entretanto, para reprimir e prevenir a devastação ecológica, que a empresa venha a ser, em casos extremos, penalmente responsabilizada. Mesmo porque muitas vezes é ela quem se beneficia economicamente da atividade ilícita. Nada mais justo, portanto, sempre que o crime ecológico configurar a expressão de uma política econômica da empresa, venha ela a ser atingida pelo direito penal especial.

6. O tipo penal que tutela a ecologia não poderá conter enumeração taxativa da conduta delituosa. O ideal seria que a contivesse, 
em nome da certeza do direito. A miopia do legislador, todavia, que não poderá prever todas as manifestações antiecológicas, o constrange a elaborar um tipo penal mais elástico, em que as condutas são enumeradas exemplificativamente.

Também: sempre em favor da certeza do direito, preferível seria que o tipo penal fosse acromático, incolor, desprovido de elementos valorativos. No campo do direito penal ecológico, entretanto, tal se faz inviável. O elemento valorativo muitas vezes se contém, no tipo. Veja-se, à guisa de exemplo, o caso de desfiguração ou alteração das belezas naturais, conceito eminentemente subjetivo.

Por outro lado, os próprios elementos descritivos do tipo contêm certa indeterminação, como os termos degradação e poluição. Isto sem falar nos termos técnicos (v.g., biodegradável), dos quais irá servir-se a lei penal.

Muitas normas penais em branco, complementadas pelo direito administrativo que irá fornecer as regras técnicas, irão compor, necessariamente, o direito penal ecológico, que tem natureza complenientar e acessória com relação àquele.

7 Constitui tarefa das mais árduas estabelecer o nexo causal entre a conduta antiecológica e o evento de ano. Como disse Jorge de Figueiredo Corrêa, a prova que deverá ser feita a respeito é verdadeiramente diabólica. Assim, o legislador penal preferiu substituir o evento de dano pelo de perigo, o que equivale a retroceder no momento consumativo do delito, da lesão efetiva para a simples ameaça.

Mais ainda. Via de regra, o legislador penal se contenta com o perigo abstrato ou presumido, afastando do tipo o perigo concreto, em que se verifica a sua existência caso por caso.

Em certas legislações, a impaciência do legislador penal para proteger o que ainda resta da reserva ecológica, fá-lo retroceder ainda mais o momento consumativo do crime. Veja-se, a respeito, a lei italiana de 1971, que reprime até a conduta preparatória: "produzir ou armazenar para o comércio detergentes sintéticos". Reprime-se, pois, a mera conduta, independentemente da verificação do resultado. A doutrina vislumbra, "in casu", os chamados crimes obstáculos, que constituem a fronteira avançada do direito penal.

Adotado pelo tipo penal o perigo meramente abstrato, o juiz não deve valorar nada, além do meio através do qual atua a ameaça. Não se faz portanto necessário o exame da lesão, ou ameaça de lesão ao bem tutelar.

Como se vê, o crime ecológico, em sua essência, é um delito de desobediência. A norma penal não impõe ao agente um comando para impedir o evento lesivo à natureza. Limita-se obrigá-lo a cumprir apenas as prescrições administrativas. 
Em resumo: o tipo penal consubstancia a violação de um dever formal de obediência, as normas extrapenais que regulamentam a matéria.

8. O direito penal ecológico não contém causas de justificação especiais. Só aquelas costumeiras, como o exercício regular de um direito (por ex., a descarga autorizada).

Dificilmente o estado de necessidade terá aplicação. Se direito penal é balanceamento de bens e interesses, haverão que preponderar sempre aqueles de natureza social, que não poderão ser jamais sacrificados.

A ação socialmente adequada poderá ser naturalmente invocada como nos casos daqueles que poluem o meio ambiental, em proporção mínima, lançando detritos por ocasião da realização de piqueniques.

Fala-se igualmente do risco consentido, como quando se usam anticriptógamos na agricultura.

A permissão da autoridade administrativa justifica naturalmente a conduta. Mais até. Se a autorização da autoridade estiver contida no tipo penal, a conduta será considerada atípica pelo aplicador da lei penal, e não justificada. Como se vê, a essência do crime está na desobediência. A autorização faz desaparecer o fato típico.

Acrescente-se finalmente que a jurisprudência italiana chega a examinar a legitimidade de regulamentos administrativos. Parece ela exceder, nesse aspecto, suas atribuições, invadindo inclusive poderes que não lhe parecem pertinentes. O mesmo se diga da Suprema Corte do Japão que condenou, em decisão recente, empresa que poluía o meio ambiente, embora autorizada pelas autoridades administrativas e embora seguisse as prescrições destas, no sentido de reduzir ao mínimo a carga poluidora.

9 Se o tipo penal configurar simplesmente a desobediência aos preceitos administrativos impostos, será supérflua qualquer indagação, por parte do magistrado penal, acerca do elemento subjetivo. Estaremos diante daqueles crimes em que se nota a presença do "dolus in re ipsa", de que falou Franco Bricola, em sua estupenda monografia. A certeza será meramente formal. A vontade delitiva está implícita, diante da realização de determinadas condutas vetadas.

10. As sanções comumente aplicadas são as penas de reclusão e as pecuniárias.

Entretanto, como na matéria se cogita da aplicação do princípio de que "societas puniri potest" de outras sanções haverá que se cogitar. Algumas reflexões se fazem necessárias, antes da enumeração. Pode parecer injusto, para alguns sócios que não tenham participado da deliberação societária, a aplicação da pena pecuniária à empresa. Note-se, contudo, que as vantagens econômicas auferidas pela empresa com a descarga poluidora justificam por si mesmas a aplicação da pena, que poderá ser inclusive deduzida do imposto de renda. De mais a 
mais, via de regra a conduta faz parte integrante da política empresarial, da qual participam todos os órgãos diretivos.

$\mathrm{Na}$ Alemanha, a "Ordenungwidrigkeiten" retiram a "Gelbusse" da qualidade do ilícito e da gravidade da culpa. A multa diária aplicável (Tagessätzen) vai de dois a dez mil marcos. Como o código penal alemão (St GB) estabelece que a pena pecuniária não pode superar setecentos e vinte dias, chega-se à conclusão de que a pena máxima aplicável será de setecentos e vinte mil marcos, o que já é uma soma respeitável, mesmo para uma empresa de grande porte.

Faz-se uma crítica ao ordenamento germânico, de que a pena pecuniária do crime ecológico não leva em consideração nem a vantagem auferida pela empresa, nem a sua capacidade patrimonial. A sanção do direito suíço (Busse) é fixada segundo as condições econômicas da empresa e não de acordo com o grau da culpa. O ideal seria que todos os critérios fossem combinados: a gravidade da culpa, a qualidade do ilícito, a vantagem econômica obtida e a capacidade patrimonial da empresa.

As legislações penais cogitam ainda de medidas acessórias, como a interdição do estabelecimento. Para esses casos, a lei belga prevê a obrigatoriedade do cumprimento do contrato de trabalho.

Outras legislações, como a alemã, prevêem o confisco de bens (Verfall), para reprimir as vantagens econômicas indevidas na empresa. A legislação italiana prevê o confisco dos aparelhos, utensílios e instrumentos empregados na poluição hídrica.

Algumas legislações aplicam a pena pecuniária à empresa, bem como aos dirigentes e funcionários desta que forem responsáveis pelo crime.

Uma outra sanção importante, que algumas legislações adotam, é a obrigação de "facere", estabelecida na sentença, para neutralizar as causas da poluição.

No caso de reincidência, o "Rivers Pollution Act" prevê a transformação da pena pecuniária em detentiva, ou no seu sensível agravamento.

11. O velho Código Penal Brasileiro em vigor, de 1940, pune de forma meramente mediata o meio ambiental. Assim, somente quando houver dano efetivo à saúde pública, ao patrimônio, ou quando se verificar o envenenamento, a corrupção ou poluição de água potável é que o direito penal poderá ser acionado. Atualmente, com a atividade altamente meritória da Cetesb, desde que esta prescreva determinadas medidas que não venham a ser executadas pelas empresas, poderão os seus responsáveis responder pelo crime de desobediência.

O código de 69 , que não chegou a entrar em vigor, mostrava-se um pouco mais avançado, na repressão aos abusos ecológicos, embora distante das legislações mais modernas a respeito. Estabelecia ele o 
combate à poluição atmosférica. E no campo da poluição hídrica, contentava-se com o simples lançamento de poluentes nas águas, potáveis ou não, para o aperfeiçoamento da conduta delitiva.

De todo o exposto se vê que o legislador penal brasileiro precisa cogitar de imediato do assunto. Antes que seja tarde demais. E que providencie com urgência uma lei especial que previna e reprima o crime ecológico, onde a empresa deverá ser necessariamente responsabilizada. 